\title{
Food waste solution at home: conventional and rapid composting techniques
}

\author{
${ }^{1}$ Mohamed Raimi, H.S., ${ }^{1}$ Tuan Ismail, T.N.H., ${ }^{2}$ Mohamed Najib, M.Z. and \\ ${ }^{1}$ Mohamed Yusop, F. \\ ${ }^{1}$ Department of Civil Engineering Technology, Faculty of Engineering Technology, Universiti Tun Hussein \\ Onn Malaysia 86400 Batu Pahat, Johor, Malaysia \\ ${ }^{2}$ Department of Water and Environmental Engineering, School of Civil Engineering, Universiti Teknologi \\ Malaysia, 81310 Skudai, Johor Bahru, Johor, Malaysia
}

\section{Article history: \\ Received: 1 April 2020 \\ Received in revised form: 18 \\ August 2020 \\ Accepted: 22 August 2020 \\ Available Online: 27 \\ December 2020}

\section{Keywords:}

Food waste management

Decomposition technique,

Conventional and rapid

composting

\section{DOI:}

https://doi.org/10.26656/fr.2017.4(S6).016

\begin{abstract}
Food waste is a significant concern in waste management in recent years due to the inevitable outcome of human consumption in modern society. It has happened in almost every home daily. In Malaysia, $44.5 \%$ of organic waste $(\mathrm{OW})$ consists of food waste (FW), this figure would increase with population growth. Therefore, without effective FW management, untreated FW dumping will cause environmental pollution, thus affecting human health as well as ecosystems. Conventional methods such as landfill and incineration have long been the most popular practice to address the FW issues, offering simple and cost-effective approach. Most of the time, these methods are not sustainable since they pose other environmental pollution such as greenhouse gas (GHG) emissions and leachate contamination leading to groundwater pollutions. Other issues with landfills are that self-composting at landfill site takes a long time and most landfills in Malaysia are almost at full capacity. The composting technique has recently gained more attraction as a cost-effective and sustainable method for the FW issue. This paper reviews techniques of composting food waste at home by using a conventional natural and rapid process. The performance of each technique in terms of cost, sustainability, user-friendly and time are measured in this review. Finally, the future direction of food waste solution by sustainable composting technique is briefly discussed in this paper.
\end{abstract}

\section{Introduction}

Food waste refers to the biodegradable wasted, unused, uneaten and inedible food that is produced during preparation, distribution, and consumption being discarded in the food supply chain (Saravanan et al., 2013; Lim et al., 2016). Food waste also includes either expired or left to spoil. Over the last decade, food waste has become a huge environmental issue faced throughout the world, in which waste generation rapidly increasing in tandem with population growth, rapid urbanization, rising living standards, and a booming economy (Melikoglu et al., 2013; Abdel-Shafy and Mansour, 2018). Paritosh et al. (2017) reported that 278 to 416 million tonnes were generated annually in Asian countries from 2005 to 2025 due to population and economic growth. Moreover, Chan et al. (2011) and Johari et al. (2014) claim that $45 \%$ of the municipal solid waste is food waste and continues to rise year by year. As stated by the Solid Waste Management and Public
Cleansing Corporation, SWCorp (2016) and SWCorp (2017), Malaysia's daily domestic waste reaches 37,500 tons/day. The remaining $44.5 \%$ of the residue is $\mathrm{FW}$ with approximately $16,687.5$ tons, of which $12,682.5$ tons is the unavoidable food waste $(76 \%)$, while 4005 tons of food waste can be avoided (24\%) that can be consumed by 2,970,000 people for three meals. SWCorp also reports that each person is estimated to produce $1.17 \mathrm{~kg}$ of unavoidable food per day with an average weight of one serving per person being $0.45 \mathrm{~kg} / \mathrm{meal}$. It is believed that $1 / 4$ of the food is wasted during the preparation, production and consumption process. The growing purchasing power in line with the booming economy has driven people to buy more than they need and a healthier lifestyle, which is expected $\mathrm{FW}$ to expand to $30 \%$ by 2020 (Sreenivasan et al., 2012; Bernama, 2019).

Most food waste would ends up at the landfill, along the road-side, or in the river. It has created a host of problems that adversely affect the environment and 
threaten life on earth. SWCorp (2018) has identified nine consequences that will affect Malaysia if the FW management is not planned and enforced, It includes air pollution, leachate, underground water poluttion, odour pollution and disruption, ozone depletion, flash flood, soil acidification, dengue, and leptospirosis. However, six of which will endanger human health, and the rest will cause environmental pollution. These issues have brought enormous pressure among local governments, businesses, public, and academicians.

Currently, SWCorp under Act 672, has outlined three FW management methods undergoing in Malaysia, namely landfill, incineration and composting. On the basis of moderation and low-cost factors, landfills are the primary method practiced in Malaysia (Manaf et al., 2009). Nonetheless, the disposal of food waste to landfills requires extensive processes which comprise of storage, collection, transportation, and ultimately ends up in landfills. Every single process poses its own environmental challenges, which are; carbon footprint potential as the garbage plastic bags are used to store the food waste, unpleasant odours, leachate pollution, and carbon dioxide emissions (Harian Metro, 2015; Oreopoulou and Russ, 2007). In fact, inadequate handling of food waste at sources allows mice to be present and spreading Leptospirosis bacteria afterwards (Harian Metro, 2015). In addition, landfill sites that are not equipped with sanitation systems will allow leachates to flow directly and eventually absorb in the soil without treatment, leading to groundwater pollution (Lacovidou et al., 2012) and soil acidification (Saer et al., 2013). Besides that, the adverse unregulated organic matter in landfills are capable of releasing greenhouse gas (GHG), methane and carbon dioxide gas by anaerobic digestion, which leads to ozone depletion (Ghafar, 2017). Moreover, many landfills currently have to be closed due to their capacity being nearly full (Hassan et al., 2001; Zainal and Hassan, 2019). The second method is incineration that has been frequently applied to manage food waste in Malaysia, mainly implemented in rural areas where waste is not collected properly. Unfortunately, such method has contributed to many environmental problems due to its high moisture content which encourages the release of toxins (Sakai et al., 2001; Misra et al., 2003; Paritosh et al. 2017). Therefore, it is important to manage food waste at sources with the right and effective solution towards green and sustainable practices (Luque and Clark, 2013; Thi et al. 2016).

Composting has recently gained attention as a viable alternative way of tackling the problem of food waste by biological process of organic substrate (Ramdzan et al., 2018), which involves the activity of the mesophilic and thermophilic bacterial populations under certain moisture, aerobic or anaerobic conditions to produce a product in the form of powder which are stable, low in moisture and free from pathogen (Iyengar and Bhave, 2006; Soares et al., 2013; Sheets et al., 2015). The composting method not only minimizes the volume of food waste dump to landfill, but also its ended compost product is beneficial as a fertilizer and soil alteration without adverse effects on the environment (Iyengar and Bhave, 2006; Yang et al., 2006; Tsai et al., 2007). Nevertheless, the main problems concerning the natural decomposition are too lengthy process, release unhealthy odours and gas arising from trace volatile organic compounds upon its decomposition. Muttalib et al. (2016) reported that it takes more than four months to produce compost, where it cannot meet with daily waste generated by each source (household, restaurants, institutional cafeteria, industrial lunchrooms, etc.). Furthermore, Muttalib et al. (2016) also stated that the harmful odour has significant effects on human health because the hydrogen sulfide $\left(\mathrm{H}_{2} \mathrm{~S}\right)$ gas is highly toxic, which produces an annoying rotten egg odour. Rapid decomposition techniques by using vermicomposting, shredding and frequent turnings, silos or the use of additive materials (cellulolytic cultures, mineral nitrogen activator, effective microorganism (EM) and enzyme) have introduced as the most effective and sustainable solution to tackle food waste issues. Nevertheless, until now, food waste are still dumped into landfills and possess vast environmental issues to the community. This is due to insufficient research and a lack of understanding and knowledge over different factors that affect the whole decomposition process. The present paper is therefore written to extensively discuss the challenges and benefits of various food waste composting techniques for the future direction of sustainable food waste management. This paper also deals with the factor affecting the effectiveness of additive materials in the decomposition process.

\section{Trend and analysis of food waste composting based on scholar search}

The food waste composting trend was analysed on the basis of the count of documents retrieved from scholarly data sources that are currently integrated with the Lens (lens.org). The scholar search indicates that the total number of documents relating to the food waste composting published to date is 5009 , with the citation of 105206. The published document shows an increasing trend in the last 20 years, which is from 2000 to 2019 , as shown in Figure 1. It can be concluded that food waste generation is becoming a worrying issue throughout world. 


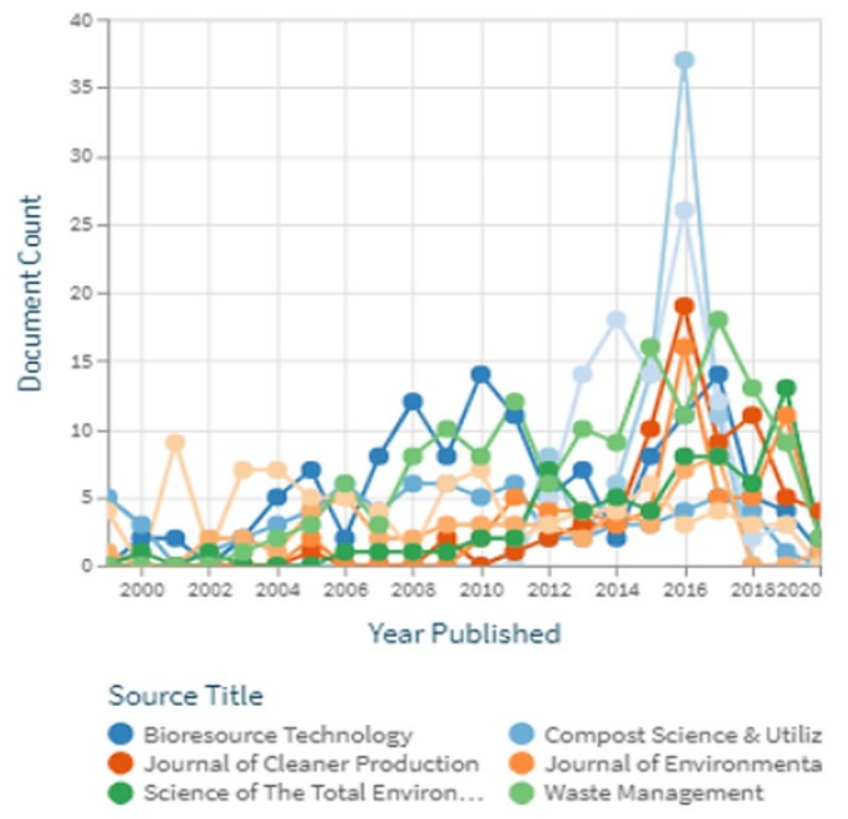

Figure 1. Document published on food waste composting within 20 years. Source: LENS.ORG (2002)

However, the increase in writing related to food waste composting reached its peak by 131 publications in 2016, after that, it continued to decrease through 2019, reaching only 46 publications. The decline of the related publications was not due to problems being resolved but people increasingly unaware of the problem. There has been little public response to all education campaigns and programs organized by the authorities and nongovernmental organizations (NGOs) (Zainu and Songip, 2017). Moreover, the community is not well trained in the management of solid waste (SW), especially food waste. Researchers are starting to get bored, and all their efforts are being wasted because they cannot benefit the community. This paper, therefore, aims to promote awareness of the FW management while providing a convenient and low-cost guideline for the public to encourage them to practice the management of FW using simple, fast and cheap composting technology.

According to the trend of publication in Malaysia, it shows that the research is fluctuates beginning from 2000 to 2019. The data recorded show that within 20 years the total number of documents are 110. This obviously shows that the issues surrounding food waste have not been addressed until now, it consequently indicates that the composting techniques are an effective solution to that.

\section{Important factor affecting decomposition process of food waste}

The process of decomposition, also known as aerobic digestion, is the process by which food waste is broken down into nutrient-rich substances called organic fertilizers or better known as compost. Based on the discussion above, it can be summarized that the important factors affecting the rate of decomposition process are particle size, moisture, carbon to nitrogen ratio and temperature (Chang and Hsu, 2008; Chang et al., 2010; Wang et al., 2018; Chan, 2016).

\subsection{Particle size}

Particle size is one of the physical factors which may affect the efficiency of composting. The cutting, shredding or grinding of raw materials into a smaller size $(1.5$ to $4 \mathrm{~cm})$ helps to promote the efficiency of decomposition by increasing the total surface area to allow more microbial invasion (Chan, 2016). Besides, it can make the particles in uniform size, improve the aeration, retain the moisture and increase the value of the final product. The particle size, however, cannot be too small, since it is likely to compress the entire composting mass (Raabe, 1981; Chan, 2016). This resulting in pore spaces to be drastically reduced and insufficient spaces do not enable movement of oxygen which leads to anaerobic conditions.

\subsection{Moisture}

Sufficient moisture is important to ensure the growth and survival of the microorganisms, thus, it should be maintained in a range of 50 to $60 \%$ throughout the decomposition process. However, according to Saad et al. (2013), the moisture content should remain between 50 to $70 \%$. In this situation, moisture or water is not only a by-product but also a reactant for bacterial reactions, where the moisture during composting can greatly influence the diffusivity of gas through the substrates. During composting, microbial reactions can be suppressed under low moisture conditions, and dry composting mass is considered physically stable but biologically unstable, in which the decomposing process is sluggish. Conversely, composting mass with high moisture content inhibits air movement, thereby the oxygen cannot diffuse without ample pore spaces leading to an anaerobic state. This condition produces a soggy layer, which slows down the process and smells. Therefore, pore spaces are essential to provide adequate oxygen for the aerobic microorganisms in a composting system. The frequency of turning the composting materials will help uniformly redistribute the moisture and dry the wet materials out.

\subsection{Temperature}

The changes in temperature are important indicators for monitoring the status of microbial activities during the decomposition process (Ugwuanyi et al., 1999; Kumar et al., 2010). The microbes that make up the majority of decomposition process fall into two categories, which are; (a) mesophilic, which microbes 
that live and function at the temperature of 10 to $45^{\circ} \mathrm{C}$, and (b) thermophilic, which microbes that thrive at the temperature of 45 to $70^{\circ} \mathrm{C}$. Maintaining an optimal temperature within the range can, therefore, be a requirement for faster and more complete composting. Heat retention in bins is better than in open compost container, therefore fast composting is more efficient when using bins.

\subsection{Carbon to nitrogen $(C / N)$ ratio}

The carbon to nitrogen ratio $(\mathrm{C}: \mathrm{N})$ is an important source for microorganisms to convert organic materials into compost. Carbon is effectively used to serve as an energy source for microorganisms to decompose organic matter while nitrogen $(\mathrm{N})$ is used for the synthesis of proteins, enzymes and other structural components. Chan (2016) stated that the ratio of carbon to nitrogen $(\mathrm{C} / \mathrm{N}$ ratio) should be balanced, and the optimal condition to have a better microbial decomposition is within the range of 25 and 30. In the composting process, the efficiency of decomposition will slow down when carbon-rich substrate too much while the nitrogen is used up to cause the organism's death. In contrast, if there is high nitrogen substrate of starting materials but not enough carbon, excess nitrogen will emit as $\mathrm{NH}_{3}$, which cannot be used to complete the nitrogen cycle (Chan, 2016).

\section{Food waste composting technique}

Composting is an aerobic method of decomposing organic solid waste gradually, which means the presence of air is needed to process it. Barthod et al. (2018) reported that the composting consists of three main phases, which are initial activation, followed by a thermophilic and a maturation phase. Although the process of composting food waste has a high potential for promotion, there is still a lack of implementation, which is deficient in operation and management, and it further exacerbates the awareness and skills that have undermined public confidence in the effectiveness of this method in managing its FW (Körner and Visvanathan, 2013).

Therefore, five common types of composting techniques are used at home to speed up the decomposition process of food waste, such as heat, shallow compartment, effective microorganism (EM), activator and vermicomposting, which have been introduced and practiced in Malaysia. On the basis of the following composting techniques, it can be divided into two categories, namely conventional natural and rapid process. The heat and shallow compartments are two techniques used as a natural decomposition process. However, Saad et al. (2013) claimed that the conventional composting is rarely been used because of longer time needed to reach maturity phase. The vermicomposting, Effective Microorganism (EM) and activator were also discussed as a one of rapid composting techniques to enhance the overall potential of the decomposition process.

\subsection{Heat (compost pile)}

Heat technique was the earliest method introduced around 1969 in India and South Africa (Habsah, 2008). The heating technique is suitable in covered or sheltered areas that receive moderate rainfall or decomposition process. It can be done either pile up into a shallow windrow 1.5 to $2.0 \mathrm{~m}$ high and 2.5 to $4.0 \mathrm{~m}$ wide (static windrow) or stack openly.

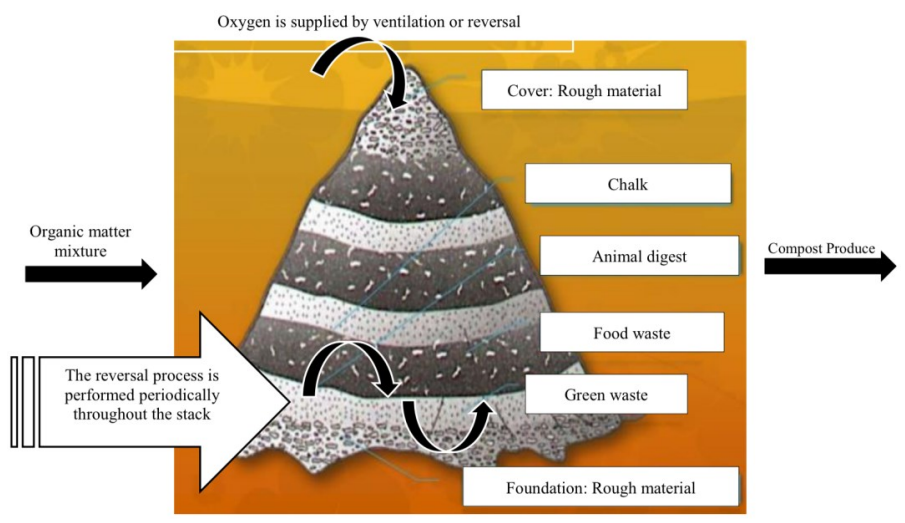

Figure 2. Decomposition process of FW use heat technique (modified from Habsah, 2008)

Figure 2 shows each of the suggested composting layers using the heat method. The compost will have to be rotated manually or by machines, it depends on the pile size. Besides that, the ventilation process also plays a significant role in improving the degradation properties of organic matter. This process is intended to prevent deposition in conjunction with the release of water vapour, gases and heat trapped (Jabatan Perancangan Bandar dan Desa Semanjung Malaysia (JPBD), 2013). Regrettably, this method is seen as a major environmental obstacle, especially when it is exposed to external elements during the decomposition process, which will not be completed properly and produces an unpleasant odour and smells of the presence of pests such as insects and mice. This can, however, be resolved with proper care, but the cost of hiring specialized workers to manage FW remains growing. Here, it is evident that this technique is severe and does not achieve the main aim of introducing easy-to-do decomposition techniques at home. Furthermore, heat technique requires a large amount of space, equipment, or machinery to handle the process of reversal, and additional costs are required to pay the workers performing the work of reversal. This concludes that heat technique costs a lot of money in general. Moreover, according to Misra et al. 
(2003), heating technique may be complemented by additives such as cow dung and water to improve the efficiency of the composting process.

\subsection{Shallow compartment}

The technique of shallow compartment is a method of composting that takes place in a covered area or in a special building. Through this process, the waste is collected at a depth of less than two meters in the upper part of the open compartment. Figure 3 displays the Shallow compartment technique of the FW decomposition process. In this process, ventilation can be done manually every week or two by reversing compost. The floor area of the compartment can be modified by providing a drainage system for leachate discharge and air ventilation (JPBD, 2013). This method gives a better effect of using green waste, brown waste or dried twigs as composting agents. However, this technique gets tough with the high cost of site preparation and maintenance. Due to the high cost of site preparation and management is the challenge of this technique, and this technique is also inadequate in the housing sector, which is commonly known for housing in narrow and dense urban areas. Nonetheless, this strategy gets tough with the high cost of site preparation and management, as well as being inadequate at limited space and dense areas like urban, because this technique requires a large space.
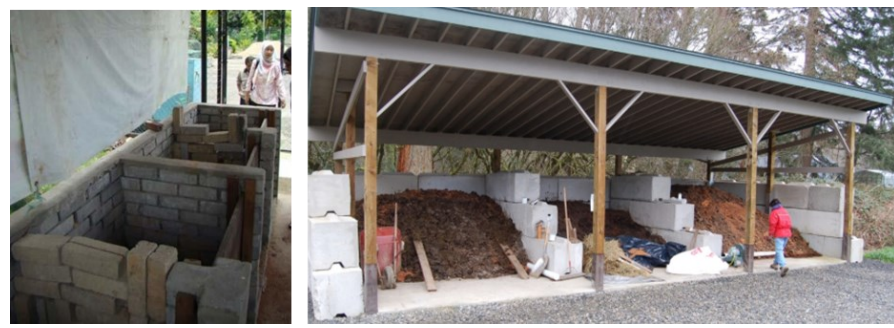

Figure 3. Food waste composting using Shallow compartment technique (JPBD, 2012)

\subsection{Vermicomposting}

Vermicomposting is a process of decomposition using earthworms to consume organic waste and convert it into organic matter called vermicast or worm stools were otherwise known as compost (Majlessi, et al., 2012). Not all worm species fit for decomposition purposes. The striped worm or tiger worm or its scientific name Eisena foetida is the most popular and readily available species. Alternatively, the red cava or fungus worm known as Lumbricus rubellus is another species that can be used. As stated in JPBD (2013), both worm species usually live in stools, compost heaps, and plant material rich in organic matter. Worms have a higher content of macro-and micronutrients than garden compost. Vermicompost products are also rich in Nitrogen (N), Phosphorus (P) and Potassium (K), which are is good for growth (Othman, 2012; Majlessi, et al., 2012). Furthermore, to prevent disease in plants, worm development in the soil also known as Aerators indirectly helps to improve the preservation of air and water (Salman, 2019). However, worm is capable of performing all the microbial and mechanical work required in the $\mathrm{FW}$ compaction phase such as a turner and serves as an accelerator which can consume $500 \mathrm{~g}$ to $1000 \mathrm{~g} \mathrm{FW}$ within a day and generate around 160-350 g of casting which is $1 / 3$ of FW consumed (JPBD, 2012). The users will face some challenges as this procedure is not user-friendly as it is unsuitable to be done at home because human find worms disgusting. Furthermore, users also have trouble finding suitable worms. This worm is also very light and heat-sensitive.

\subsection{Effective Microorganism (EM)}

Effective Microorganism (EM) is a mixture of a number of organisms that will have a good impact on humans, animals, plants and nature (Higa and Parr, 1994). Good bacteria, such as Phobic (biotic) in the EM function, help inhibit the growth of pathogenic bacteria in the growth system. Crop cultivation consisting of three main types of bacteria called lactic acid bacteria, photosynthetic bacteria and yeast provides, in principle, simple, economical and environmentally friendly methods. Higa (1991) was the first to discover EM for the use of organic crops in 1970 (Higa and Wididana, 1991; Sangakkara, 2002). Up to now, thte use of EM has expanded to the extent that it can be used for decomposition, septic tank cleaning, bio mediation and domestic use. The EM manufacturing industry is booming, manufacturers are no longer using natural materials as their recipes due to high demand factors and reduced production costs. As stated by Formowitz et al. (2007) EMs sold on the market today contain chemicals. Nevertheless, EM is commonly used as an accelerator in the composting process, and adds mineral value to compost products (Jusoh et al., 2013) but the outcome of compost products is no longer sustainable toward the environment. EM inoculants can be produced on their own, but the process is quite challenging and will cost a lot of money. Consequently, the EM techniques do not encourage the public to write their own FWs, because they believe it is more economical and efficient to leave their FWs at the landfill site.

\subsection{Compost activator}

Compost activator is a microbial inoculant as a result of fermentation of certain substrates within a specific period to enhance microbial reproduction which include bacteria or fungi (Yang, et al., 2006; Pauze, 2015). The activator compost contains a combination of carbohydrates, glucose, and microorganisms effectively 
used to accelerate the decomposition process. They are mixed and left for a particular time until the fermentation is complete based on odour and physical observation. In this process, the carbohydrates and glucose act as food and energy sources to the microbes. Rice water, tuber, carrots, potatoes, banana peel and banana stem are commonly used as a carbohydrates sources. Glucose composed of brown sugar, white sugar, coconut water, and sugarcane. While microorganism are extracted either from animals (fish and urine), vegetables (bamboo lead, spinach, lettuce, apples, tomatoes, and sprouts), yogurt, stale rice, tape (fermented cassava) or tempeh (fermented soybeans) (Panda et al., 2016). Leff and Fierer (2013) stated that fruits including apples and grapes, and vegetables like spinach, lettuce, peaches, sprouts, peppers, and tomatoes harbor large populations of microorganisms.

According to Pavlis (2017), the compost activator is also known as the accelerator and starter, but by any name, they do the same thing that speeds up the natural decomposition processes in the compost container. Takakura composting method is currently the most popular approach that uses the Native Microorganism's biodegradable decomposition, it was discovered in Kitakyushu, Japan by Koji Takakura (Acosta et al., 2012). This is a fast, simple, and inexpensive composting technique. The activator by Takakura composting method requires a mixture of fermentation solution and fermenting beds. The fermentation solution contains various forms of fermenting microorganisms made from a combination of fermented foods (yogurt, soy sauce, fermented soybeans, yeast, etc.) and sugar water (brown sugar and water), or it can be made by mixing salted water (salt and water) with fruit peels (grape, orange, apple or papaya) and vegetables (cucumber, lettuce, pumpkin, etc.). Those fermentation solutions are left for 3 to 5 days for the fermentative microorganism to grow. Based on Takakura Method, the fermenting solutions are complete when it smells sweet and sour. Then, the mature fermentation solution is mixed with the fermentation bed. Fermenting bed is one of the important medium to promote maximum bacteria activity. Mixtures of rice husk and coconut peat or rice husk and dry peat soil or rice husk bran are used to make the fermenting bed. The mixture is closed and keep to proliferation of bacteria for 10 to 14 days. At this stage, the moisture should be adjusted to $40-60 \%$ by adding the fermenting solution and water, as the moisture content is right the mixture becomes a lump without oozing water when being squeezed gently in the palm hand. Moreover, the activator's ability as an inhibitor depends on the choice of vegetable and fruit peel and the exact ratio of organic waste to molasses (Formowitz et al., 2007). Consequently, Takakura composting approach is, therefore, easily followed at home with variations of safe activators and the processing time is also shorter than other techniques (Garcia-Garcia et al., 2017; JiménezAntillón et al., 2018). Moreover, compost products are thought free of any chemical elements.

\section{Conventional natural versus rapid composting techniques}

The conventional composting refers to the decomposition process under natural conditions by monitoring environmental factors, without adding any types of microbes or additive materials. Meanwhile, with the aid of microbes and additive materials, the decomposition process is achieved through rapid composting such as vermicomposting, effective microorganism (EM) and activator composts. In this process, to have an excellent performance, the moisture, temperature, and $\mathrm{pH}$ value should be within the range as described previously. Control of the carbon-nitrogen ratio to 1:30 is also essential, thus preventing temporary nutrient immobilisation.

Table 1 summarises the performance of conventional and rapid composting in terms of cost, sustainability, user-friendly and time, output from various sources. The conventional composting techniques require high preparation, maintenance, and equipment costs as well as

Table 1. Performance of various composting techniques in term of cost, sustainability, user friendly and time

\begin{tabular}{|c|c|c|c|c|c|c|}
\hline & \multirow{2}{*}{ Technique } & \multirow{2}{*}{ References } & \multicolumn{4}{|c|}{ Performance } \\
\hline & & & Cost & Sustainability & User- Friendly & Time (week) \\
\hline \multirow{2}{*}{$\begin{array}{l}\varrho \\
0 \\
0 \\
0 \\
0.0 \\
0 \\
0\end{array}$} & Heat (compost pile) & $\begin{array}{l}\text { Misra, et al. (2003); Habsah (2008); JPBD } \\
\text { (2012) }\end{array}$ & High & Low & Low & $16-32$ \\
\hline & $\begin{array}{l}\text { Shallow } \\
\text { Compartment }\end{array}$ & Sulistyorini (2005); JPBD (2012) & High & Low & Low & $16-32$ \\
\hline \multirow{3}{*}{ 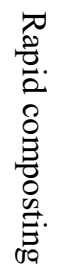 } & Vermi-composting & Misra, et al. (2003); JPBD (2012) & Low & High & Low & $4-8$ \\
\hline & $\begin{array}{c}\text { Effective } \\
\text { Microorganism (EM) }\end{array}$ & El-Hamied (2014) & Moderate & Doubted & High & $2-6$ \\
\hline & Compost activator & $\begin{array}{l}\text { Iyengar and Bhave, (2006); Thi et al., } \\
\text { (2016); Garcia-Garcia et al. (2017) }\end{array}$ & Low & High & High & $2-4$ \\
\hline
\end{tabular}


occupying large areas, thus it is unsuitable for urban areas. Moreover, due to a long-term period of 16 to 32 weeks (1 to 3 months) to complete the process, the conventional techniques are not sustainable, since it will produce an unpleasant odour and smells, and toxic gas emissions. Furthermore, the sustainability of EM technology is doubtful because the majority of EMs currently on the market are made from chemicals (Daly et al., 1999; Formowitz et al., 2007). Compared to others, activator composts and vermicomposting are the most sustainable approaches, as they are prepared with locally-available materials at home and natural-available materials in our environment, respectively. Vermicomposting, however, is difficult to take care of, and not easy to find the suitable worm. It is different from compost activator and EM which require only mixing with food waste and will be appropriate for home use. In addition, with these techniques, compost can be made in two to six weeks. This paper has clarified that rapid composting is the best way to compose our food waste at home.

\section{Conclusion}

The present paper reviewed the conventional composting and rapid composting techniques that were adopted for home use, with the aim to manage food waste at the sources. Therefore, our main goal is to promote awareness among people to know how to manage their own household FW at the sources with a guideline. At the end we will pass on cleaner earth to our future generations.

The composting method is the best method that can be used to overcome the food waste issues, and it has been proven to reduce the amount of organic waste that is converted to quality compost products that can improve soil quality and crop growth. Overall, the rapid composting techniques provide a better performance compared to conventional composting, which the cycle is complete and composting can be achieved in a short period of a time; less than 2 months. Also, it is noticeable that the compost activator is the most suitable technique that can be used at home if being done as described. It is cheap and easy to implement because the material used can be obtained from domestic materials at home and from FW itself and then mixed with some cheap materials, which require mixing of all materials in the basket. Fermentative microorganisms play a central role in composting. Since fermentative microorganisms which perfectly suit composting inhabit our immediate surroundings, anyone can easily make effective compost by finding and culturing them. The effective use of fermentative microorganisms enables the production of a large amount of compost in a small space and in a short period of time. This solution provides a positive impact on technology, economics, ecosystems, health, and social benefits.

\section{Acknowledgement}

The authors would like to thank the Ministry of Higher Education for financial support under Fundamental Research Grant Scheme Vot. No. FRGS/1/2018/TK10/UTHM/03/3 and partially sponsored by Universiti Tun Hussein Onn Malaysia.

\section{References}

Abdel-Shafy, H.I. and Mansour, M.S. (2018). Solid waste issue: Sources, composition, disposal, recycling, and valorization. Egyptian Journal of Petroleum, 27(4), 1275-1290. https:// doi.org/10.1016/j.ejpe.2018.07.003

Acosta, V., Paul, J., Lao, C., Aguinaldo, E. and Valdez, M.D.C. (2012). Development of the Philippines national solid waste management strategy 20122016. Environmental Sciences Procedia, 16, 9-16. https://doi.org/10.1016/j.proenv.2012.10.003

Barthod, J., Rumpel, C. and Dignac, M.F. (2018). Composting with additives to improve organic amendments. A review. Agronomy for Sustainable Development, 38, 17. https://doi.org/10.1007/s13593 $-018-0491-9$

Bernama. (2019). 16650 Ton Sisa Makanan Dibuang Setiap Hari. Retrieved on October, 2019 from myMetro Website: https://www.hmetro.com.my/ mutakhir/2019/04/445042/ 16650-tan-sisa-makanandibuang-setiap-hari. [In Bahasa Malaysia].

Chan, M.T. (2016). Optimizing food waste composting process in fed-batch composter. Hong Kong: Hong Kong Baptist University, MSc thesis.

Chan, Y.C., Sinha, R.K. and Wang, W. (2011). Emission of greenhouse gases from home aerobic composting, anaerobic digestion and vermicomposting of household wastes in Brisbane (Australia). Waste Management and Research, 29(5), 540-548. https:// doi.org/10.1177/0734242X10375587

Chang, J.I. and Chen, Y.J. (2010). Effects of bulking agents on food waste composting. Bioresource Technology, 101(15), 5917-5924. https:// doi.org/10.1016/j.biortech.2010.02.042

Chang, J.I. and Hsu, T.E. (2008). Effects of compositions on food waste composting. Bioresource Technology, 99(17), 80688074. https://doi.org/10.1016/j.biortech.2008.03.043 
Chua, K.H., Sahid, E.J.M. and Leong, Y.P. (2011). Sustainable municipal solid waste management and GHG abatement in Malaysia presented at the $15^{\text {th }}$ International Conference on ISO and TQM, July 2628, 2011, p. 1-8. Malaysia.

Daly, M.J. and Stewart, D.P.C. (1999). Influence of "effective microorganisms" (EM) on vegetable production and carbon mineralization-a preliminary investigation. Journal of Sustainable Agriculture, 14 (2-3), 15-25. https://doi.org/10.1300/J064v14n02_04

El-Hamied, S.A.A. (2014). Improving growth and productivity of "Sukkary" mango trees grown in North Sinai using extracts of some brown marine algae, yeasts and effective microorganisms 2Productivity and fruit quality. Middle East Journal of Applied Sciences, 4(3), 460-470.

Formowitz, B., Elango, F., Okumoto, S., Müller, T. and Buerkert, A. (2007). The role of "effective microorganisms" in the composting of banana (Musa ssp.) residues. Journal of Plant Nutrition and Soil Science, 170(5), 649-656. https://doi.org/10.1002/ jpln.200700002

Garcia-Garcia, G., Woolley, E., Rahimifard, S., Colwill, J., White, R. and Needham, L. (2017). A methodology for sustainable management of food waste. Waste and Biomass Valorization, 8(6), 22092227. https://doi.org/10.1007/s12649-016-9720-0

Ghafar, S.W.A. (2017). Food Waste in Malaysia: Trends, Current Practices and Key Challenges presented at the FFTC Agricultural Policy Platform (FFTC-AP).

Habsah, N.M.S. (2008). Pengkomposan sisa taman menggunakan kaedah timbunan statik berudara dan drum berputar. Pulau Pinang, Malaysia: Universiti Sains Malaysia, MSc. Thesis. [In Bahasa Malaysia].

Harian Metro. (2015). Sisa Makanan Biak Tikus. Retrieved on February 25, 2020, from Harian Metro Website: https://www.hmetro.com.my/ mutakhir/2015/07/65405/sisa-makanan-biak-tikus. [In Bahasa Malaysia].

Hassan, M.N., Chong, T.L., Rahman, M., Salleh, M.N., Zakaria, Z. and Awang, M. (2001). Solid waste management in Southeast Asian countries with special attention to Malaysia. Proceedings of 8th International Waste Management and Landfill Symposium, p. 1-5. Italy.

Higa, T. (1991). Effective microorganisms: A biotechnology for mankind. Proceedings of the $1^{\text {st }}$ International Conference on Kyusei Nature Farming, p. 8-14. Washington: US Department of Agriculture.

Higa, T. and Parr, J.F. (1994). Beneficial and effective microorganisms for a sustainable agriculture and environment. Atami, Japan: International Nature
Farming Research Center.

Higa, T. and Wididana, G.N. (1991). The concept and theories of effective microorganisms. Proceedings of the $1^{\text {st }}$ International Conference on Kyusei Nature Farming, p. 118-124. Washington: US Department of Agriculture.

Iyengar, S.R. and Bhave, P.P. (2006). In-vessel composting of household wastes. Waste Management, 26(10), 1070-1080. https:// doi.org/10.1016/j.wasman.2005.06.011

Jabatan Perancangan Bandar Dan Desa Semenanjung Malaysia. (2013). Panduan Pelaksanaan Inisiatif Pembangunan Kejiranan Hijau, Program Pengkomposan Sisa 2012. Malaysia: Kementerian Kesejahteraan Bandar, Perumahan Dan Kerajaan Tempatan.

Jiménez-Antillón, J., Calleja-Amador, C. and RomeroEsquivel, L.G. (2018). Food Waste Recovery with Takakura Portable Compost Boxes in Offices and Working Places. Resources, 7(4), 84. https:// doi.org/10.3390/resources 7040084

Johari, A., Alkali, H., Hashim, H., Ahmed, S.I. and Mat, R. (2014). Municipal solid waste management and potential revenue from recycling in Malaysia. Modern Applied Science, 8, 37 - 49. https:// doi.org/10.5539/mas.v8n4p37

Jusoh, M.L.C., Abd Manaf, L. and Latiff, P.A. (2013). Composting of rice straw with effective microorganisms (EM) and its influence on compost quality. Iranian Journal of Environmental Health Science and Engineering, 10, 17. https:// doi.org/10.1186/1735-2746-10-17

Körner, I. and Visvanathan, C. (2013). Perspectives of composting and anaerobic digestion technologies for the treatment of organic fraction of municipal solid waste in Europe and Asia. International Journal of Environment and Waste Management, 11(2), 193212. https://doi.org/10.1504/IJEWM.2013.051844

Kumar, M., Ou, Y.L. and Lin, J.G. (2010). Cocomposting of green waste and food waste at low $\mathrm{C} /$ $\mathrm{N}$ ratio. Waste Management, 30(4), 602-609. https:// doi.org/10.1016/j.wasman.2009.11.023

Lacovidou, E., Ohandja, D.G., Gronow, J. and Voulvoulis, N. (2012). The household use of food waste disposal units as a waste management option: A review. Critical Reviews In Environmental Science And Technology, 42(14), 1485-1508. https:// doi.org/10.1080/10643389.2011.556897

Leff, J.W. and Fierer, N. (2013). Bacterial communities associated with the surfaces of fresh fruits and vegetables. PloS One, 8(3), 0059310. https:// doi.org/10.1371/journal.pone.0059310 
The Lens. (2020). Scholarly Analysis Dashboard. Retrieved from The Lens website: https:// www.lens.org/lens/search/scholar/list? $\mathrm{q}=\&$ dateFilterField $=$ year_published\&filterMap $=\% 7 \mathrm{~B} \%$ 7D\&orderBy $=\% 2$ Breferenced_by_count\&preview $=$ true

Lim, W.J., Chin, N.L., Yusof, A.Y., Yahya, A. and Tee, T.P. (2016). Food waste handling in Malaysia and comparison with other Asian countries. International Food Research Journal, 23(Suppl.), S1-S6.

Luque, R. and Clark, J.H. (2013). Valorisation of food residues: waste to wealth using green chemical technologies. Sustainable Chemical Processes, 1(1), 1-3. https://doi.org/10.1186/2043-7129-1-10

Majlessi, M., Eslami, A., Saleh, H.N., Mirshafieean, S. and Babaii, S. (2012). Vermicomposting of food waste: assessing the stability and maturity. Iranian Journal of Environmental Health Science and Engineering, 9, 25. https://doi.org/10.1186/17352746-9-25

Manaf, L.A., Samah, M.A.A. and Zukki, N.I.M. (2009). Municipal solid waste management in Malaysia: Practices and challenges. Waste Management, 29 (11), 2902-2906. https://doi.org/10.1016/ j.wasman.2008.07.015

Melikoglu, M., Lin, C. and Webb, C. (2013). Analysing global food waste problem: pinpointing the facts and estimating the energy content. Open Engineering, 3 (2), 157-164. https://doi.org/10.2478/s13531-0120058-5

Misra, R.V., Roy, R.N. and Hiraoka, H. (2003). On-farm composting methods. Rome, Italy: Food and Agriculture Organization of the United Nations (UNFAO).

Muttalib, S.A., Ismail, S.N.S. and Praveena, S.M. (2016). Applications of Effective Microorganism (EM) in Food Waste Composting: A Review. Asia Pacific Environmental and Occupational Health Jurnal, 2(2), 37-47.

Oreopoulou, V. and Russ, W. (Eds.). 2007. Utilization of by-products and treatment of waste in the food industry. New York, NY, USA: Springer. https:// doi.org/10.1007/978-0-387-35766-9

Othman, N. (2012). Vermicomposting of food waste. International Journal of Integrated Engineering, 4, 39-48.

Panda, S.K., Mishra, S.S., Kayitesi, E. and Ray, R.C. (2016). Microbial-processing of fruit and vegetable wastes for production of vital enzymes and organic acids: Biotechnology and Scopes. Environmental Research 146, 161-172. https://doi.org/10.1016/ j.envres.2015.12.035
Paritosh, K., Kushwaha, S.K., Yadav, M., Pareek, N., Chawade, A. and Vivekanand, V. (2017). Food waste to energy: an overview of sustainable approaches for food waste management and nutrient recycling. BioMed Research International, 2017, 2370927. https://doi.org/10.1155/2017/2370927

Pauze, T. (2015). Ensuring Clean and Green environment: Our role. Solid Waste Management and Public Cleansing Corporation (SWCorp).

Pavlis, R. (2017). Garden Myths - Learn the truth about gardening. Retrieved on April 2019 from Gardenmyths Website: https:// www.gardenmyths.com/compost-acceleratorsstarters-and-activators/

Perbadanan Pengurusan Sisa Pepejal dan Pembersihan Awam (SWCorp). (2017). Hargai Makanan Elakkan Pembaziran. Kementerian Perumahan dan Kerajaan Tempatan. Retrieved on November 25, 2019 from Swcorp Website: http://www.swcorp.gov.my/ docfile/2019/pendidikan/POSTER_HARGAI\% 20MAKANAN\%20ELAKKAN\% 20PEMBAZIRAN.pdf. [In Bahasa Malaysia].

Raabe, R.D. (1981). Food waste composting: Institutional and industrial applications. Malaysia: University of Georgia, MSc thesis.

Ramdzan, S.N., Abdul Kadir, A., Kamil, M., Filzah, N.A., Shahabuddin, N.A.S. and Mizad, M. (2018). Implementation of food waste composting in Malaysia. In Water and Environmental Issues. Vol. 2, p. 35-44. Malaysia: Penerbit UTHM.

Saad, N.F.M., Ma'min, N.N., Zain, S.M., Basri, N.E.A. and Zaini, N.S.M. (2013). Composting of mixed yard and food wastes with effective microbes. Jurnal Teknologi, 65(2), 89-95. https://doi.org/10.11113/ jt.v65.2196

Saer, A., Lansing, S., Davitt, N.H. and Graves, R.E. (2013). Life cycle assessment of a food waste composting system: Environmental impact hotspots. Journal of Cleaner Production, 52, 234244. https://doi.org/10.1016/j.jclepro.2013.03.022

Sakai, S.I., Hayakawa, K., Takatsuki, H. and Kawakami, I. (2001). Dioxin-like PCBs released from waste incineration and their deposition flux. Environmental Science and Technology, 35(18), 3601-3607. https:// doi.org/10.1021/es001945j

Salman, Z. (2019). Composting with worm. Retrieved on February 26, 2020 from BioEnergy Consult Website: https://www.bioenergyconsult.com/ vermicomposting/

Sangakkara, U.R. (2002). The technology of effective microorganisms: Case studies of application. United Kingdom: Royal Agricultural College. 
Saravanan, P., Kumar, S.S. and Ajithan, C. (2013). Ecofriendly practice of utilization of food wastes. International Journal of Pharmaceutical Sciences Innovation, 2(1), 14-17.

Sheets, J.P., Yang, L., Ge, X., Wang, Z. and Li, Y. (2015). Beyond land application: Emerging technologies for the treatment and reuse of anaerobically digested agricultural and food waste. Waste Management, 44, 94-115. https:// doi.org/10.1016/j.wasman.2015.07.037

Soares, M.A., Quina, M.M. and Quinta-Ferreira, R.M. (2013). Co-composting of Eggshell Waste in Selfheating Reactors: Monitoring and end product quality. Bioresource Technology, 148, 293-301. https://doi.org/10.1016/j.biortech.2013.08.151

Solid Waste and Public Cleansing Management Corporation (SWCorp). (2018). Pengurusan Sisa Pepejal Bersepadu. Retrieved on Jan 2020, from Jabatan Pengurusan Sisa Pepejal Negara Website: https://jpspn.kpkt.gov.my/index.php/pages/view/202. [In Bahasa Malaysia].

Solid Waste and Public Cleansing Management Corporation (SWCorp). (2016). Survey on Solid Waste Composition, Characteristics and Existing Practice of Solid Waste Recycling in Malaysia. Unpublished data.

Solid Waste and Public Cleansing Management Corporation (SWCorp). (2015). Retrieved on December 2017, from SWcorp Website: www.swcorp.gov.my.

Sreenivasan, J., Govindan, M., Chinnasami, M. and Kadiresu, I. (2012). Solid waste management in Malaysia: A move towards sustainability. In Rebello, L.F.M. (Ed.) Waste Management: An Integrated Vision, p. 55-70. InTech Open E-Book. https:// doi.org/10.5772/50870

Sulistyorini, L. (2005). Pengelolaan sampah dengan cara menjadikannya kompos. Jurnal Kesehatan Lingkungan, 2, 77-84. [In Bahasa Indonesia].

Thi, N.B.D., Lin, C.Y. and Kumar, G. (2016). Waste-towealth for valorization of food waste to hydrogen and methane towards creating a sustainable ideal source of bioenergy. Journal of Cleaner Production, 122, 29-41. https://doi.org/10.1016/ j.jclepro.2016.02.034

Tsai, S.H., Liu, C.P. and Yang, S.S. (2007). Microbial conversion of food wastes for biofertilizer production with thermophilic lipolytic microbes. Renewable Energy, 32(6), 904-915. https:// doi.org/10.1016/j.renene.2006.04.019
Ugwuanyi, J.O., Harvey, L.M. and McNeil, B. (1999). Effect of process temperature, $\mathrm{pH}$ and suspended solids content upon pasteurization of a model agricultural waste during thermophilic aerobic digestion. Journal of Applied Microbiology, 87(3), 387-395. https://doi.org/10.1046/j.13652672.1999.00831.x

Wang, T., Zhai, Y., Zhu, Y., Li, C. and Zeng, G. (2018). A review of the hydrothermal carbonization of biomass waste for hydrochar formation: Process conditions, fundamentals, and physicochemical properties. Renewable and Sustainable Energy Reviews, 90, 223-247. https://doi.org/10.1016/ j.rser.2018.03.071

Yang, J., Zhao, Y., Shi, J. and Shao, F. (2013). Human NAIP and mouse NAIP1 recognize bacterial type III secretion needle protein for inflammasome activation. Proceedings of the National Academy of Sciences, 110(35), 14408-14413. https:// doi.org/10.1073/pnas. 1306376110

Yang, S.Y., Ji, K.S., Baik, Y.H., Kwak, W.S. and McCaskey, T.A. (2006). Lactic acid fermentation of food waste for swine feed. Bioresource Technology, 97(15), 1858-1864. https://doi.org/10.1016/ j.biortech.2005.08.020

Zainal, D. and Hassan, K.A. (2019). Factors influencing household food waste behaviour in Malaysia. International Journal of Research in Business, Economics and Management, 3(3), 56-71.

Zainu, Z.A. and Songip, A.R. (2017). Policies, challenges and strategies for municipal waste management in Malaysia. Journal of Science, Technology and Innovation Policy 3, 18-22. 